\title{
Incidence, Distribution, and Association of Spongospora subterranea and Potato mop-top virus in Costa Rica
}

\author{
Mauricio Montero-Astúa and Viviana Vasquéz, Centro de Investigación en Biología Celular y Molecular \\ (CIBCM), Universidad de Costa Rica (UCR), San Pedro 2060, Costa Rica; William W. Turechek, United States \\ Department of Agriculture-Agricultural Research Service, Subtropical Plant Pathology Unit, Fort Pierce, FL 34945; \\ Ueli Merz, Plant Pathology, Institute of Integrative Biology, ETH Zurich, Switzerland; and Carmen Rivera, \\ CIBCM and Facultad de Microbiología, UCR
}

\begin{abstract}
Montero-Astúa, M., Vasquéz, V., Turechek, W. W., Merz, U., and Rivera, C. 2008. Incidence, distribution, and association of Spongospora subterranea and Potato mop-top virus in Costa Rica. Plant Dis. 92:1171-1176.

A survey was conducted in 39 potato (Solanum tuberosum) fields in Costa Rica to determine incidence and association of Spongospora subterranea f. sp. subterranea and Potato mop-top pomovirus (PMTV). The fields were located in Costa Rica's two major potato-production regions and were further characterized by their altitude. In all, 633 paired samples of leaf tissue and corresponding tubers were collected, assessed visually for disease, and subsequently assayed by enzyme-linked immunosorbent assay (ELISA). S. subterranea presence in tuber tissue was tested by double-antibody sandwich (DAS)-ELISA and PMTV presence in leaf and tuber tissues was tested by triple-antibody sandwich (TAS)-ELISA. Moreover, soil samples were collected from 10 fields surveyed and were evaluated for both pathogens via ELISA and bioassay. The incidence of both diseases ranged from 0 to $100 \%$ within individual fields, with incidences lower than $40 \%$ occurring in more than $70 \%$ of the fields. Higher incidences were found in fields located at higher altitudes. Of the 633 paired samples, 179 and 146 were positive for PMTV and $S$. subterranea, respectively, according to ELISA in either the foliage or tubers. A low correlation was found for PMTV visual symptoms and ELISA test results. Only 14 of the 81 foliar samples testing positive for PMTV had visual symptoms; the remaining 67 samples were asymptomatic. Conversely, comparison of visual evaluation with detection of $S$. subterranea by ELISA on tubers showed that $70 \%$ of the results were coincident. S. subterranea was detected in 4 of 10 soil samples tested by ELISA. Soilborne PMTV was detected by ELISA in roots of bait plants sown in these soil samples. Co-occurrence of both pathogens was detected in 64 samples. A significant but low degree of association for vector and virus was determined, and data suggests that $S$. subterranea is participating in the transmission of PMTV in Costa Rica in low frequency.
\end{abstract}

Additional keywords: epidemiology

Powdery scab of potato (Solanum tuberosum L.) is caused by the plasmodiophorid Spongospora subterranea (Wallr.) Lagerh. f. sp. subterranea J.A. Toml. (17). S. subterranea is also a vector of Potato mop-top virus (PMTV; 2,14). The diseases are recognized as important threats to potato production in Northern Europe, China, Japan, South America, and Australia (12,36), and the presence of PMTV was recently confirmed in North America (39). Both diseases have been detected in Costa Rica

Corresponding author: M. Montero-Astúa

E-mail: montero-mau@ costarricense.cr

V. Vasquéz died 14 December 2005.

Accepted for publication 17 March 2008.

doi:10.1094/PDIS-92-8-1171

This article is in the public domain and not copyrightable. It may be freely reprinted with customary crediting of the source. The American Phytopathological Society, 2008.
$(23,34)$, where no information on their epidemiology exists.

Powdery scab and PMTV are mainly blemish diseases of potato tubers. The symptoms of powdery scab are occasionally difficult to recognize and may be confused with common scab, caused by Streptomyces spp. S. subterranea causes lesions on tuber skin, cankers, and tuber deformation $(8,13,17)$, and has been shown to affect plant growth and yield $(9,13)$. PMTV causes "spraing" of potato, which is characterized by the presence of rust-colored necrotic arcs and patterns in the flesh or the skin of the tubers (4). However, PMTV is erratically distributed through the plant and asymptomatic infection of the tubers is common in some cultivars $(11,27,36)$.

S. subterranea and PMTV can be found in soil or in potato tubers used as seed. In the soil, the virus survives for long periods of time in association with $S$. subterranea resting spores $(14,15)$. Therefore, dissemination of both pathogens within or between fields can occur through the movement of infested soil or infected tubers
$(14,15)$. Studies using artificially spiked soil have shown that $S$. subterranea can be detected directly by enzyme-linked immunosorbent assay (ELISA) with a detection limit of 100 sporosori/g of soil $(22,38)$. However, the vector and virus can be detected with greater efficiency in soil using a bioassay with bait plants $(19,21,32,38)$. The bioassay has been coupled with ELISA and polymerase chain reaction (PCR) techniques for quantitative detection of both pathogens $(1,32)$; however, it has been suggested that ELISA testing of soil samples may be more useful than the bioassay for predicting disease intensity on tubers (38).

No chemical treatment is available for effective control of $S$. subterranea or PMTV. The most efficient measure for prevention of disease is avoidance; that is, to plant clean seed into uninfested soil (20). Therefore, knowledge of vector and virus presence in soil is a crucial component to disease management (6). Moreover, the relative importance of each source of inoculum in the development of the disease in the field is unknown, and it is difficult to study this aspect of their epidemiology due to the complexities and uncertainties of the pathogen's biology (6). The objectives of this research were to (i) determine the incidence of $S$. subterranea and PMTV in commercial potato-growing regions in Costa Rica and (ii) determine the magnitude of association between $S$. subterranea and PMTV.

\section{MATERIALS AND METHODS}

Field survey and sample collection. Thirty-nine potato fields were sampled throughout Costa Rica's main potatogrowing areas, Cartago (cultivated area estimated at 2,400 ha) and Zarcero (approximately 270 ha). Samples were collected throughout 2002 and the first six months of 2003. In all, 25 fields were sampled in Cartago, identified as Car-1 to Car-25, and 13 fields were sampled in Zarcero, labeled Zar-1 to Zar-13. A field (RR-1) dedicated to tuber seed production in Rancho Redondo area was also sampled. The Cartago area was stratified according to altitude into a zone below 1,800 $\mathrm{m}$ above sea level (m.a.s.l.), a zone between 1,800 and 2,500 m.a.s.l., and a zone above 2,500 m.a.s.l. The altitude of Zar- 
cero extends from 1,500 to 2,100 m.a.s.l. The majority of sampled fields were planted with either cv. Granola or cv. Floresta (clone CIP386040.9). Nevertheless, some growers had mixed plantations or had other cultivars during the survey. Growers obtained their seed from local seed producers or they used their own seed produced from the previous crop.

Individual fields were variable in size, with most being less than one-half of a hectare. In all, 10 or 20 plants were sampled in each field according to field size with one exception, where 15 plants were sampled in Car-10. Fields were divided into two (10 samples), four (20 samples), or three (15 samples) subplots and, from each subplot, five plant samples were chosen in the same "zig-zag" pattern. Several leaves were taken randomly from each plant during bloom and two or three tubers from the same plant were collected at harvest. Due to some losses, the final number of paired samples of leaf tissue and corresponding tubers collected was 633. Incidence of PMTV or S. subterranea at each field was calculated based on ELISA results (tests described below).

Soil samples were collected at 10 of the surveyed fields. Soil was collected from around each plant sampled at the corresponding field and mixed together to get a composite field sample. These 10 soil samples were left to air dry at room temperature in the laboratory (approximately $20^{\circ} \mathrm{C}$ ) for a minimum of 10 weeks where they were tested for $S$. subterranea by ELISA and used subsequently as inoculum in a modified bioassay to test for PMTV (19).

Evaluation of foliar and tuber tissue samples. Visual rating of foliar tissue. The 633 foliar samples were visually inspected for the presence of PMTV-like symptoms (aucuba, chevrons, and calico spots arranged in "V" pattern) prior to ELISA testing for the virus as described below.

Visual rating of tuber tissue. Tuber samples were stored in paper bags upon arrival at the laboratory and kept between 18 and $22^{\circ} \mathrm{C}$ for approximately a month before evaluation (27). To rate tubers, each sample was lightly washed under running tap water and dried overnight on a paper towel. Tuber samples were visually evaluated for the presence of powdery-scab-like lesions. Observations were scored per plant (sample) as "positive" for tubers with powdery scab lesions, "negative" for tubers with no apparent lesions or deformities, or "doubtful" for tubers in which lesions and deformities existed but appeared different than powdery scab. Afterward, tuber samples were tested for the presence of $S$. subterranea and PMTV.

ELISA testing for PMTV. The presence of PMTV in potato leaves and tuber samples was tested by triple-antibody sandwich (TAS)-ELISA using specific commercial antibodies (Neogen Europe Ltd.,
Auchincruive, Scotland, UK) following the manufacturer's instructions. Foliar tissue samples were ground 1:5 (wt/vol) in general extraction buffer $(0.010 \mathrm{M} \mathrm{NaSO}$, $0.001 \mathrm{M} \mathrm{KH} \mathrm{KO}_{4}, 0.008 \mathrm{M} \mathrm{Na} \mathrm{NPO}_{4}$, $0.136 \mathrm{M} \mathrm{NaCl}, 0.002 \mathrm{M} \mathrm{KCl}, 2 \%$ polyvinyl-pyrrolidone [PVP; wt/vol], $0.05 \%$ Tween 20 [vol/vol], and $0.2 \%$ egg albumin [wt/vol], $\mathrm{pH}$ 7.4). For tuber analysis, one or two flesh tissue cubes $(0.5 \times 0.5 \times 0.5$ $\mathrm{cm})$ were taken from the midregion of each tuber and ground $1: 1(\mathrm{wt} / \mathrm{vol} ; 24)$ in general extraction buffer in a plastic sample bag lined with mesh (Agdia Inc., Elkhart, IN). No new shoot growth was present on the tubers at the time of testing. Samples were tested in duplicate and all plates included certified negative and positive controls. Plates were read after $60 \mathrm{~min}$ in a Dynex MRX microplate reader at $405 \mathrm{~nm}$ (Dynex Technologies, Chantilly, VA).

ELISA testing for S. subterranea. S. subterranea presence on tubers was tested by double-antibody sandwich (DAS)-ELISA using commercial monoclonal antibodies specific for $S$. subterranea sporosori (BIOREBA AG, Reinach, Switzerland) according to the manufacturer's instructions. For each sample, tuber skin tissue was peeled off at two different sites on each tuber (average weight, $0.10 \mathrm{~g}$ ). When typical or suspicious powdery-scab lesions were present, these areas were chosen for analysis. The skin tissue was ground 1:10 (wt/vol) in tuber extraction buffer $(0.020$ M Tris, $0.136 \mathrm{M} \mathrm{NaCl}, 0.002 \mathrm{M} \mathrm{KCl}, 2 \%$ PVP [wt/vol], $0.05 \%$ Tween 20 [vol/vol], and $1 \%$ egg albumin [wt/vol], pH 7.4). Samples were tested as described above, but read after $120 \mathrm{~min}$.

Samples tested for either PMTV or $S$. subterranea with ELISA absorbance values higher than the mean of the negative controls plus three standard deviations were considered positive (29).

Data analysis. For each pathogen, a $\chi^{2}$ test was used to determine whether the proportion of positive samples between Cartago and Zarcero and among the different altitude zones at Cartago differed significantly (40). A two-by-two and threeby-two table, respectively, were constructed for these analyses.

A $\chi^{2}$ test of independence was used to test for association between the apparent visual foliar symptoms of PMTV and its corresponding detection by ELISA (40); the Yates continuity correction factor was applied to this two-by-two table. The same analysis was used to test for association between disease ratings of powdery scab obtained from visual evaluation of tubers and its detection by ELISA; a three-by-two table was constructed for this analysis. Cramer's $V^{2}$ was used to measure the strength of association for each test (10). Cramer's $V^{2}$ is a $\chi^{2}$-based measure of nominal association and, like most indices of association, gives a value from 0 to 1 . The index is preferred to other measures because it corrects for table size; however, the maximum value of 1 can only be achieved when row and column marginals are equal. $V^{2}$ is calculated as $\chi^{2} / n m$, where $n$ is the sample size and $m$ is the smaller of (rows - 1) or (columns - 1).

Detection of $S$. subterranea and PMTV in soil samples. For each soil sample, $0.3 \mathrm{~g}$ of soil was homogenized in $1.0 \mathrm{ml}$ of tuber extraction buffer in a microcentrifuge tube for approximately $30 \mathrm{~s}$. The macerate was left to settle for 15 to 30 min and the supernatant was used for detection of $S$. subterranea sporosori by ELISA as described above. Autoclaved soil from a field where potato was never planted served as a negative control and a commercial $S$. subterranea-positive control (BIOREBA AG) were included in all plates.

The presence of soilborne PMTV was tested in the soil samples by a bioassay. Tomato (Lycopersicon esculentum Mill. cv. Supermarmande), Nicotiana benthamiana Domin., and N. tabacum L. var. Xanthi were used as bait plants. Tomato seed were planted in plastic nursery trays filled with sterilized hydroponic media $(50 \%$ quartz sand $/ 50 \%$ grounded coconut fiber). The seeds were watered with a threefold dilution of a modified Hoagland's nutrient solution containing $1.48 \mathrm{mM} \mathrm{NH} \mathrm{NH}_{2} \mathrm{PO}_{4}$, $6.34 \mathrm{mM} \mathrm{Ca}\left(\mathrm{NO}_{3}\right)_{2}, 5.44 \mathrm{mM} \mathrm{KNO}_{3}, 2.04$ $\mathrm{mM} \mathrm{MgSO}{ }_{4} 0.05 \mathrm{mM} \mathrm{H}_{3} \mathrm{BO}_{3}, 0.001 \mathrm{mM}$ $\mathrm{CuSO}_{4}, 0.008 \mathrm{mM} \mathrm{MnSO}{ }_{4}, 0.003 \mathrm{mM}$ $\mathrm{ZnSO}_{4}, 0.00005 \mathrm{mM} \mathrm{NaMoO}$, and 0.012 $\mathrm{mM}$ Fe-EDTA, adjusted to $\mathrm{pH} 5.2$ and electric conductance of $2 \mathrm{dSm}^{-1}$. The seed were kept in a Percival E-30B growth chamber (Percival Scientific, Inc., Perry, IA) with a 24 -h light period at $22^{\circ} \mathrm{C}$ for 7 days. Afterward, the growth conditions were adjusted to $16 \mathrm{~h}$ of light at $18^{\circ} \mathrm{C}$ and $8 \mathrm{~h}$ of darkness at $15^{\circ} \mathrm{C}$ for an additional 6 weeks. $N$. benthamiana and $N$. tabacum L. var. Xanthi seed were sown in hydroponic media and placed in a growth chamber set for $16 \mathrm{~h}$ of light at $18^{\circ} \mathrm{C}$ and $8 \mathrm{~h}$ of darkness at $15^{\circ} \mathrm{C}$ for 1 week. Thereafter, plantlets were kept in the laboratory at approximately $20^{\circ} \mathrm{C}$ for 4 weeks.

To perform the bioassay, bait plants were transferred to plastic pots filled with $150 \mathrm{~g}$ of the soil samples. There were three plants per pot, three pots per soil sample, and one pot for each plant species. Bait plants planted in disinfested soil were used as a negative control. Plants were maintained in the laboratory at approximately $20^{\circ} \mathrm{C}$ for 3 months. They were then removed from their pots and the roots were washed under tap water and frozen until ELISA testing 1 week later. To perform the ELISA, the entire root system of the bait plant was ground in $1 \mathrm{ml}$ of general extraction buffer (the same used for leaf tissue) and samples were tested for PMTV in duplicate as described above for leaf tissue.

Statistical analysis of the association between PMTV and $S$. subterranea. The 
association between PMTV and S. subterranea was determined with the Jaccard index of similarity $(J)$ for the 633 paired foliar and tuber samples (31). In addition, the index was calculated for subsets of the data in separate analyses by region (i.e., Cartago and Zarcero) as well as by altitude within the Cartago region. The values of the index ranged from 0 to unity, where values close to 1 are suggestive of a high degree of association and values close to 0 represent dissociation. The Jaccard index was calculated using: $J=a /(a+b+c)$, where $a$ represents the number of samples where both the virus and vector occurred, $b$ represents the number of samples where the virus occurred but the vector was absent, and $c$ represents the number of samples where the vector occurred but the virus was absent. The Jaccard similarity index does not make use of the number of samples where neither the virus nor its vector occurred. Therefore, it represents the probability of both the virus and vector being present in the same sample within the set of samples where virus or vector are found.

To test the null hypothesis of independence, a $Z$ statistic was calculated using the procedure described by Turechek (31). In short, randomizations of the data were used to calculate a value, $\bar{J}_{\text {ran }}$, which represents the expected value of the index if the virus and its vector were distributed independently given their observed incidences (i.e., under the null hypothesis of independence). A nonparametric estimate of the standard error of the Jaccard index, $s_{\mathrm{j}}$, was obtained using the jackknife procedure (18).

To test whether the observed Jaccard index was significantly different from the value calculated under the assumption of independence, a normal distribution was assumed for the index estimated by $J$ (the observed Jaccard value) and standard error estimated by the jackknifed value, $s_{J}$. A standard normal statistic was calculated using:

$$
Z=\frac{J-\bar{J}_{r a n}}{s_{j}}
$$

Treating $Z$ as a two-sided test, values of $Z$ $>1.96$ indicate significant positive association and values of $Z<-1.96$ indicated significant negative association or dissociation at $P=0.05$.

Association was also assessed using the $\chi^{2}$ test of independence and its magnitude was determined with Cramer's $V^{2}$ as described above. These were calculated for comparison with the Jaccard index because these statistics use different information to measure association.

\section{RESULTS}

Field survey. S. subterranea was detected by ELISA in at least one tuber sample in 28 of the 39 potato fields surveyed: in 16 out of 25 fields at Cartago, in 11 out of 13 fields at Zarcero, and in the potato plantation at Rancho Redondo (Table 1). PMTV was detected in at least one leaf or tuber sample in 35 fields: 24 at Cartago and 11 fields at Zarcero (Table 1). S. subterranea and PMTV incidences were below $40 \%$ in more than $70 \%$ of the fields, but incidences of $100 \%$ were found for both diseases in single but separate fields.

The proportion of the total number of $S$. subterranea-positive samples (Table 2) was similar at Cartago (80/394) and Zarcero $(54 / 225)(P=0.3104)$. However, there was a significant difference between the proportion of PMTV-positive samples between Cartago (134/394) and Zarcero $(45 / 225)(P=0.0002)$. Disease incidence for both $S$. subterranea and PMTV at Cartago showed a tendency to vary with altitude, with disease incidence being greater at higher altitudes. This can be seen at the field level (Table 1) and among the individual paired samples (Table 2). The highest incidence of PMTV and S. subterranea was found at altitudes greater than 2,500 m.a.s.l. at Cartago. When the proportions of the total number of positive

Table 1. Number of potato fields within each incidence class testing positive by enzyme-linked immunosorbent assay to Spongospora subterranea (S) and to Potato mop-top pomovirus $(\mathrm{P})$ in relation to the region of production and elevation in Costa Rica ${ }^{\mathrm{a}}$

\begin{tabular}{|c|c|c|c|c|c|c|c|c|c|c|c|c|c|c|}
\hline \multirow[b]{4}{*}{ Class } & \multicolumn{8}{|c|}{ Cartago } & & & & & & \\
\hline & \multicolumn{6}{|c|}{ Elevation $^{b}$} & & & & & & & & \\
\hline & \multicolumn{2}{|c|}{$>2,500(7)$} & \multicolumn{2}{|c|}{$2,500-1,800(9)$} & \multicolumn{2}{|c|}{$<1,800(9)$} & \multicolumn{2}{|c|}{ All (25) } & \multicolumn{2}{|c|}{ Zarcero (13) } & \multicolumn{2}{|c|}{$\mathbf{R R}^{\mathbf{c}}(\mathbf{1})$} & \multicolumn{2}{|c|}{ Total (39) } \\
\hline & $\mathbf{S}$ & $\mathbf{P}$ & $\mathbf{S}$ & $\mathbf{P}$ & $\mathbf{S}$ & $\mathbf{P}$ & $\mathbf{S}$ & $\mathbf{P}$ & $\mathbf{S}$ & $\mathbf{P}$ & $\mathbf{S}$ & $\mathbf{P}$ & $\mathbf{S}$ & $\mathbf{P}$ \\
\hline 0.00 & 0 & 0 & 3 & 0 & 6 & 1 & 9 & 1 & 2 & 2 & 0 & 1 & 11 & 4 \\
\hline $0.01-0.20$ & 0 & 1 & 4 & 4 & 3 & 5 & 7 & 10 & 6 & 7 & 0 & 0 & 13 & 17 \\
\hline $0.21-0.40$ & 3 & 0 & 0 & 2 & 0 & 3 & 3 & 5 & 3 & 2 & 0 & 0 & 6 & 7 \\
\hline $0.41-0.60$ & 1 & 2 & 1 & 1 & 0 & 0 & 2 & 3 & 0 & 2 & 0 & 0 & 2 & 5 \\
\hline $0.61-0.80$ & 2 & 1 & 0 & 1 & 0 & 0 & 2 & 2 & 1 & 0 & 0 & 0 & 3 & 2 \\
\hline $0.81-1.00$ & 1 & 3 & 1 & 1 & 0 & 0 & 2 & 4 & 1 & 0 & 1 & 0 & 4 & 4 \\
\hline
\end{tabular}

${ }^{a}$ Tubers of 10, 15, or 20 plant samples per field were tested depending on the field size. Number in parentheses = total per elevation or region.

${ }^{\mathrm{b}}$ Elevation is measured in meters above sea level.

${ }^{c}$ Rancho Redondo.

Table 2. Association of Potato mop-top pomovirus (PMTV) and Spongospora subterranea based on enzyme-linked immunosorbent assay test results and calculated with the Jaccard index and Cramer's $V^{2}$ for 633 paired samples $(N=$ number of samples $)$ of foliar and tuber tissue collected at 39 different potato fields in Costa Rica

\begin{tabular}{|c|c|c|c|c|c|c|c|c|c|c|c|c|}
\hline \multirow[b]{2}{*}{ Locality $^{\mathbf{d}}$} & \multirow[b]{2}{*}{$N$} & \multicolumn{4}{|c|}{ PMTV/S. subterranea ${ }^{\mathrm{a}}$} & \multicolumn{4}{|c|}{ Jaccard analysis $^{\mathbf{b}}$} & \multicolumn{3}{|c|}{$\chi^{2}$ Analysis $^{c}$} \\
\hline & & $+/+$ & $+/-$ & $-1+$ & $-1-$ & $J$ & $s_{J}$ & $\bar{J}_{r a n}$ & $P$ & $\chi^{2}$ & $P$ & $V^{2}$ \\
\hline Cartago area & 394 & 54 & 80 & 26 & 234 & 0.338 & 0.038 & 0.146 & $<0.001$ & 50.16 & $<0.001$ & 0.1273 \\
\hline$>2,500$ m.a.s.1. & 80 & 29 & 24 & 16 & 11 & 0.420 & 0.060 & 0.438 & 0.382 & 0.150 & 0.6995 & 0.0018 \\
\hline 1,800-2,500 m.a.s.1. & 149 & 22 & 31 & 8 & 88 & 0.361 & 0.062 & 0.150 & 0.001 & 23.37 & $<0.001$ & 0.1569 \\
\hline$<1,800$ m.a.s.l. & 165 & 3 & 25 & 2 & 135 & 0.100 & 0.056 & 0.021 & 0.151 & 6.776 & 0.035 & 0.0410 \\
\hline Zarcero area & 225 & 10 & 35 & 44 & 136 & 0.112 & 0.034 & 0.122 & 0.382 & 0.097 & 0.755 & 0.0004 \\
\hline RR locality & 14 & 0 & 0 & 12 & 2 & 0.000 & $\ldots$ & $\ldots$ & $\ldots$ & & .. & . \\
\hline Total & 633 & 64 & 115 & 82 & 372 & 0.240 & 0.027 & 0.146 & $<0.001$ & 22.65 & $<0.001$ & 0.0358 \\
\hline
\end{tabular}

${ }^{a}$ Contingency table values indicating positive (+) or negative (-) test results.

b $J=$ Jaccard similarity index; $s_{J}=$ jack-knifed estimate of the standard error of $J ; J_{\text {ran }}=$ expected value of the Jaccard index if the occurrence of the two organisms is independent; $P=$ probability that $J$ is significantly different than $J_{\text {ran }}$ according to $Z$ test; ... indicates no association analysis performed because there was no PMTV detection.

${ }^{\mathrm{c}}$ Cramer's $V^{2}$ ranges from 0 to 1 , where 1 represents perfect association; ... indicates no association analysis performed because there was no PMTV detection.

${ }^{\mathrm{d}}$ Cartago area subdivided by altitude (m.a.s.l. = meters above sea level); RR = Rancho Redondo 
samples were compared for the different Cartago altitudes (Table 2), there was a statistical difference $(P<0.001)$ between each altitude for either disease.

Detection of PMTV in potato leaves and tubers. The detection of PMTV by ELISA varied among the different tissues tested on the same plant. Of the 179 plants that tested positive for PMTV, 63 samples tested positive in their foliage, 98 samples were positive in tuber tissue, and only 18 samples tested positive for PMTV in both foliar and tuber tissue simultaneously. Of the $81(63+18)$ foliar samples testing positive for PMTV, only 14 had visual symptoms; the remaining 67 samples were asymptomatic (Table 3). However, there were an additional 36 samples that had PMTV-like symptoms but tested negative by ELISA (Table 3 ). The $\chi^{2}$ test of association indicated a lack of independence between visual symptoms and ELISA test results for PMTV $\left(\chi^{2}=11.26\right.$, df $=1, P=$ 0.0008).

Detection of $S$. subterranea in potato tubers. For powdery scab, 56 samples were rated as positive, 454 as negative, and 123 as doubtful according to visual evaluation of tuber symptoms (Table 4). Comparison of visual evaluation with detection of $S$. subterranea by ELISA indicated that $70 \%$ of the results were coincident; that is, of the 510 samples that could be visually classified as $S$. subterranea positive or negative, only 61 samples were incorrectly classified when compared with ELISA results (Table 4). From these 61 samples, 47 ( $7.4 \%$ of the 633 samples) were visu-

Table 3. Contingency table for the relationship between leaf visual symptoms and enzymelinked immunosorbent assay (ELISA) test results for Potato mop-top pomovirus (PMTV)

\begin{tabular}{lccc}
\hline & \multicolumn{2}{c}{ Visual symptoms $^{\mathbf{a}}$} & \\
\cline { 2 - 3 } ELISA $^{\mathbf{b}}$ & + & - & Total \\
\hline+ & 14 & 67 & 81 \\
- & 36 & 516 & 552 \\
Total & 50 & 583 & 633 \\
\hline
\end{tabular}

a Visual symptoms observed (+) or no visual symptoms (-).

${ }^{b}$ ELISA test result confirm presence of PMTV $(+)$ or no PMTV (-).

Table 4. Contingency table for the relationship between visual symptoms and enzyme-linked immunosorbent assay (ELISA) test results for powdery scab of potato, caused by Spongospora subterranea

\begin{tabular}{lcccc}
\hline & \multicolumn{3}{c}{ Visual symptoms $^{\mathbf{a}}$} & \\
\cline { 2 - 4 } ELISA $^{\mathbf{b}}$ & + & - & $\boldsymbol{~}$ & Total \\
\hline+ & 42 & 47 & 57 & 146 \\
- & 14 & 407 & 66 & 487 \\
Total & 56 & 454 & 123 & 633 \\
\hline
\end{tabular}

a Visual symptoms observed (+), no visual symptoms (-), or visual symptoms inconclusive (?).

${ }^{\mathrm{b}}$ ELISA test result confirmed presence of $S$. subterranea (+) or no S. subterranea (-). ally rated as negative, with no apparent lesion on the tubers, but tested positive by ELISA. Conversely, 14 samples were visually rated as positive but negative by ELISA. The 123 samples rated as doubtful represented $19.43 \%$ of the total and, from these, 57 were found ELISA positive and 66 were found to be ELISA negative. The $\chi^{2}$ test of association indicated a lack of independence between visual symptoms and ELISA test results for S. subterranea $\left(\chi^{2}=164.02\right.$, df $\left.=2, P<0.0001\right)$. Cramer's $V^{2}$ was 0.2591 , indicating a low degree of association.

Detection of $S$. subterranea and PMTV in soil samples. ELISA was performed to determine pathogen presence in 10 soil samples collected as part of the survey. Of the 10 samples, 4 tested positive for $S$. subterranea. These same four soil samples also tested positive for PMTV in the bioassay (Table 5). There was no apparent association between the detection of $S$. subterranea in the soil samples and the incidence of $S$. subterranea or PMTV in the plants sampled from these fields (data not shown).

Soilborne PMTV was detected in at least one of the three bait plant species in 8 of the 10 field soil samples assayed (Table 5). Soilborne PMTV was not detected in bait plants from soil samples Car-F2 and Car-F15 and only a low absorbance value was detected in N. tabacum for soil sample Car-F11. For several soil samples, N. benthamiana produced higher PMTV titer than did tomato or N. tabacum.

Association between PMTV and $S$. subterranea. The value of the Jaccard index of association for the 633 paired samples was 0.245 , indicating a low but significant level of association $(\alpha=0.05)$ according to the randomization test (Table 2). Similarly, the $\chi^{2}$ test of independence indicated significant association, and the magnitude of association was low according to Cramer's $V^{2}$, which is in agreement with the results obtained with the Jaccard index. When the data set was stratified by elevation, results indicated that the diseases were associated at altitudes between 1,800 and 2,500 m.a.s.l., and the results were mixed at elevations below 1,800 m.a.s.l. In contrast, the two diseases occurred independently (i.e., they were not associated) at altitudes greater than 2,500 m.a.s.l. at the Cartago and Zarcero areas according to both tests.

\section{DISCUSSION}

S. subterranea and PMTV were found to occur throughout the two potato-growing regions surveyed. The incidence of each disease in most plantations was typically less than 20\% (Table 1) but incidences of $100 \%$ were detected in two fields. In Cartago, the number of samples with one or both of the pathogens increased with altitude (Tables 1 and 2). At a higher altitude lower temperatures, higher humidity, and longer periods of soil wetness may be contributing factors to the increase of disease because such conditions are favorable for the development of the vector $(33,35)$ and virus $(5,11)$.

In general, the data showed that where more PMTV occurred, more S. subterranea was detected. However, the degree of association between PMTV and S. subterranea in potato plants, as determined by the Jaccard index and Cramer's $V^{2}$, varied with altitude and production region (Table 2). The indices calculated for the complete data set and the Cartago mid-level-altitude data set showed a significant level of association $(P<0.001)$ between the virus and its vector. However, the magnitude of associations detected for these data sets were generally low, agreeing with previous findings (Table 2) (25,30). Temperature and

Table 5. Detection by enzyme-linked immunosorbent assay (ELISA) of Spongospora subterranea in field soil samples and Potato mop-top pomovirus (PMTV) in the roots of three bait plant species sown in field soil samples and in disinfested control soil ${ }^{\mathrm{a}}$

\begin{tabular}{lcccc}
\hline & & \multicolumn{2}{c}{ ELISA for } \\
\cline { 2 - 5 } Soil sample & & & PMTV & \\
\cline { 2 - 5 } Control soil & S. subterranea & L. esculentum & N. tabacum & N. benthamiana \\
Car-F2 & - & $0.036(-)$ & $0.040(-)$ & $0.038(-)$ \\
Car-F6 & - & $0.035(-)$ & $0.033(-)$ & $0.043(-)$ \\
Car-F7 & + & $0.239(+)$ & $0.283(+)$ & $0.495(+)$ \\
Car-F8 & + & $0.103(+)$ & $0.044(-)$ & $0.871(+)$ \\
Car-F10 & + & $0.211(+)$ & $0.206(+)$ & $0.708(+)$ \\
Car-F11 & - & $0.987(+)$ & $0.043(-)$ & $0.362(+)$ \\
Car-F15 & - & $0.039(-)$ & $0.067(+)$ & $0.035(-)$ \\
Car-F17 & - & $0.033(-)$ & $0.032(-)$ & $0.033(-)$ \\
Zar-F2 & - & $0.039(-)$ & $0.382(+)$ & $0.189(+)$ \\
Zar-F5 & + & $0.060(+)$ & $0.112(+)$ & $0.554(+)$ \\
No. of positives & - & $0.123(+)$ & $0.320(+)$ & $0.980(+)$ \\
\hline
\end{tabular}

a Plant bait species were Lycopersicon esculentum var. Supermarmande, Nicotiana tabacum var. Xanthi, and N. benthamiana.

${ }^{\mathrm{b}}$ ELISA absorbance value at $405 \mathrm{~nm}$. Samples with ELISA absorbance values higher than the mean of the negative controls plus three standard deviations were considered positive. Positive (+) or negative (-) samples are indicated for field soil and bait plants. 
humidity, as they change with altitude, may be factors influencing the degree of association among regions. Temperature and humidity have been noted to affect other plasmodiophorid vector-virus associations (7).

The data from the soil bioassay showed that transmission of soilborne PMTV occurred readily (Table 5), despite our inability to detect $S$. subterranea by ELISA in four of the eight PMTV-positive samples. The inability to detect $S$. subterranea suggests reduced sensitivity of the ELISA test relative to the bioassay, which would affect survey results. A similar difference in sensitivity between ELISA and bioassay was demonstrated by Walsh et al. (38). Additionally, differential susceptibility to $S$. subterranea infection has been noted between potato roots and tubers (21). Thus, root or stolon infection may be occurring in the field without a corresponding tuber infection. Both circumstances would affect the results of the survey and could explain the low degree of association between $S$. subterranea and PMTV found in this study and other studies $(25,30)$.

The degree of association and the actual infection rates for both diseases were possibly underestimated in the present work due to the limitations of the detection technique employed. ELISA is known to have lower sensitivity than PCR-based methods, such as reverse-transcriptase PCR $(1,24,27,30)$. Detection may be hampered due to the erratic distribution of PMTV in the tissue $(11,27,39)$ as well as the dormancy status and the storage conditions of the tubers $(24,27,39)$. Thus, the timing and details of the sampling methodology impact PMTV detection. In the case of $S$. subterranea, there are PCRbased methods available that are more sensitive than ELISA (26,32). Moreover, the ELISA antibodies used in this work only detect sporosori (38); thus, developing infections in the tubers may not have been detected. Testing soil samples directly by ELISA for the presence of $S$. subterranea may be affected by soil compounds or the distribution and concentration of the sporosori in the soil $(37,38)$. On the other hand, bioassay with soil samples has greater sensitivity than the ELISA technique due to an amplification effect (secondary zoospores). In future studies, it is recommended that PCR-based techniques be used, tuber samples should include tissue from both ends of the tuber, and root system samples should be analyzed as well.

Regarding the visual evaluation, no potato tuber collected during the survey showed PMTV-like spraing symptoms: slightly raised, necrotic, or partly necrotic, concentric rings (4). It is possible that cultivar resistance, environmental conditions, PMTV strain, or an interaction of one or more of these factors suppressed the development of these symptoms. It is in- teresting to note that, sometimes, a reticulate cracking on the surface of a tuber was observed, which has been strongly correlated with PMTV infection in the Andes (30). With respect to foliar infection, about $82 \%$ of the foliar samples testing positive for PMTV were asymptomatic and several foliar samples with symptoms typical of PMTV tested negative with ELISA. The symptoms of PMTV infection in potato can be confused with several other viral infections. For example, aucuba symptoms caused by PMTV in leaf tissue may be confused with symptoms caused by Alfalfa mosaic virus or Potato aucuba mosaic virus $(28,39)$.

The results obtained in this study indicate clearly that relying on symptoms to select PMTV-free plants and tubers or to make disease management decisions is not reliable (30). In this study, detection of PMTV in tubers by ELISA was greater than in foliar tissue, coinciding with former results (27). Interestingly, the detection of PMTV in tubers was not coincident with its detection in leaf tissue (i.e., few samples tested positive for PMTV in leaves and tubers simultaneously). Such inconsistencies may be due to the ELISA technique limitations discussed previously or to uneven distribution of the virus. The results indicate the need for testing of both tissues when surveying fields to avoid underestimation of virus incidence.

In contrast to PMTV, only 47 of 146 samples that tested positive for S. subterranea by ELISA were completely asymptomatic. These results suggest that visual inspection of tubers by farmers, especially in developing countries where other testing techniques may not be available, should be helpful in reducing the number of infected tubers in a seed lot. However, it should be noted that high frequency of latent tuber infection has been reported in other studies, which can be explained by unfavorable conditions for disease development (33).

Overall, it appears that vectortransmission of PMTV occurs in Costa Rica and that its importance in the transmission of the virus is determined by additional factors not revealed in this study. Future research for $S$. subterranea and PMTV should focus on understanding the factors that determine the relative importance of soilborne or seedborne inoculum in the development of the disease and modeling this virus-vector interaction. Determining the effects of climate, soil moisture, and soil characteristics should be the first step to gaining a better understanding of disease development (3) and, thus, disease management strategies. Second, PMTV is not homogeneously distributed in the plant as evidenced from ELISA data and erratic symptom development (30). Thus, additional research should be conducted to resolve the factors involved in field symptom development of PMTV. Lastly, the chemical control of the plas- modiophorid vectors of viruses is very difficult and unjustified due to economical or environmental restrains (16). The use of resistant cultivars is a control measure that can be used once a field is contaminated, but such cultivars are not yet commercially available. A possible measure to manage the spread of the diseases is to implement strict seed surveillance to avoid the contamination of disease-free fields. Additionally, field soils should be tested to evaluate soil level of infestation and use this information in an integrated management approach $(6,20)$. It is very important, in the case of Costa Rica, to evaluate the susceptibility of new cultivars prior to their commercial release in order to avoid epidemic outbreaks of the diseases as has occurred in Europe and Australia $(13,20,35)$.

\section{ACKNOWLEDGMENTS}

This work was supported by a grant from the Consejo Nacional de Ciencia y Tecnología (CONICIT) and the Ministerio de Ciencia y Tecnología (MICIT) of Costa Rica, and by the Programa de Caracterización y Diagnóstico de Virus, Viroides y Fitoplasmas (PCDV) from the CIBCM and UCR.

\section{LITERATURE CITED}

1. Arif, M., Torrance, L., and Reavy, B. 1994 Improved efficiency of detection of potato mop-top furovirus in potato tubers and in the roots and leaves of soil-bait plants. Potato Res. 37:373-381.

2. Arif, M., Torrance, L., and Reavy, B. 1995. Acquisition and transmission of potato moptop furovirus by a culture of Spongospora subterranea f. sp. subterranea derived from a single cystosorus. Ann. Appl. Biol. 126:493-503.

3. Cadle-Davidson, L., and Bergstrom, G. C. 2004. The effects of postplanting environment on the incidence of soilborne viral diseases in winter cereals. Phytopathology 94:527-534.

4. Calvert, E. L., and Harrison, B. D. 1966. Potato mop-top, a soil-borne virus. Plant Pathol 15:134-139.

5. Cooper, J. I., and Harrison, B. D. 1973. Distribution of potato mop-top virus in Scotland in relation to soil and climate. Plant Pathol. 22:73-78.

6. De Boer, R. 2000. Summary on the session on recognizing the components of an integrated control approach to powdery scab and the potato mop top virus. Pages 101-104 in: Proc. First Eur. Powdery Scab Workshop. U. Merz and A. K. Lees, eds. Scottish Agricultural College, Craibstone Estate, Aberdeen, Scotland.

7. Delfosse, P., Reddy, A. S., Thirumula Devi, K., Legrève, A., Risopoulos, J., Doucet, D., Shoba Devi, P., Maraite, H., and Reddy, D. V. R. 2002. Dynamics of Polymyxa graminis and Indian peanut clump virus (IPCV) infection on various monocotyledonous crops and groundnut during the rainy season. Plant Pathol. 51:546-560.

8. Gans, P. T. 2000. Summary of the session on symptom range and disease assessment. Pages 27-28 in: Proc. First Eur. Powdery Scab Workshop. U. Merz and A. K. Lees, eds. Scottish Agricultural College, Craibstone Estate, Aberdeen, Scotland.

9. García, R. A., García, J., Garnica, J., and Espinoza, Y. 2004. Estudio de epifitias en la roña de la papa (Spongospora subterranea) en el estado de Mérida, Venezuela. Revista Latinoamericana de la Papa, Suplemento Especial, Marzo. Oral 40.

10. Gibbons, J. D. 1985. Nonparametric Methods for Quantitative Analysis, second edition. 
American Sciences Press, Inc., Columbus, OH.

11. Harrison, B. D., and Jones, R. A. C. 1970. Host range and some properties of potato moptop virus. Ann. Appl. Biol. 65:393-402.

12. Harrison, J. G., Searle R. J., and Williams, N. A. 1997. Powdery scab disease of potato-a review. Plant Pathol. 46:1-25.

13. Hughes, I. K. 1980. Powdery scab (Spongospora subterranea) of potatoes in Queensland: occurrence, cultivar susceptibility, time of infection, effect of soil $\mathrm{pH}$, chemical control and temperature relations. Aust. J. Exp. Agric. Anim. Husb. 20:625-632.

14. Jones, R. A. C., and Harrison, B. D. 1969. The behaviour of potato mop-top virus in soil, and evidence for its transmission by Spongospora subterranea (Wallr.) Lagerh. Ann. Appl. Biol. 63:1-17.

15. Jones, R. A. C., and Harrison, B. D. 1972. Ecological studies on potato mop-top virus in Scotland. Ann. Appl. Biol. 71:47-57.

16. Kankuya, K., Ward, E., and Adams, M. J. 2003. Polymyxa graminis and the cereal viruses it transmits: a research challenge. Mol. Plant Pathol. 4:393-406.

17. Kole, A. P. 1954. A contribution to the knowledge of Spongospora subterranea (Wallr.) Lagerh., the cause of powdery scab of potatoes. Tijdschr. Plantenziekten 60:1-65.

18. Manly, B. F. J. 1997. Randomization, Bootstrap and Monte Carlo Methods in Biology, 2nd ed. Chapman \& Hall, London.

19. Merz, U. 1989. Infectivity, inoculum density and germination of Spongospora subterranea resting spores: a solution-culture test system. EPPO Bull. 19:585-592.

20. Merz, U., Jaquiery, P.-Y., Keiser, A., Oberhaensli, Th., and Walsh, J. A. 2005. Powdery scab-tools for an integrated control approach. In: 16th Triennial Conf. EAPR, Bilbao, Spain.

21. Merz, U., Martinez, V., and Schwärzel, R. 2004. The potential for the rapid screening of potato cultivars (Solanum tuberosum) for resistance to powdery scab (Spongospora subterranea) using a laboratory bioassay. Eur. J. Plant
Pathol. 110:71-77.

22. Merz, U., Walsh, J. A., Bouchek-Mechiche, K., Oberhänli, Th., and Bitterlin, W. 2005. Improved immunological detection of Spongospora subterranea. Eur. J. Plant Pathol. 111:371-379.

23. Montero-Astúa, M., Vásquez, V., and Rivera, C. 2002. Occurrence of potato powdery scab caused by Spongospora subterranea f. sp. subterranea in Costa Rica. Plant Dis. 86:1273.

24. Nielsen, S. L., and Mølgaard, J. P. 1997. Incidence, appearance and development of potato mop-top furovirus-induced spraing in potato cultivars and the influence on yield, distribution in Denmark and detection of the virus in tubers by ELISA. Potato Res. 40:101-110.

25. Nielsen, S. L., and Nicolaisen, J. P. 2000. National potato production and the powdery scab situation in Denmark. Page 13 in: Proc. First Eur. Powdery Scab Workshop. U. Merz and A. K. Lees, eds. Scottish Agricultural College, Craibstone Estate, Aberdeen, Scotland.

26. Qu, X.-S., Kavanagh, J. A., Egan, D., and Christ, B. J. 2006. Detection and quantification of Spongospora subterranea $\mathrm{f}$. sp. subterranea by PCR in host tissue and naturally infested soils. Am. J. Potato Res. 83:21-30.

27. Sokmen, M. A., Barker, H., and Torrance, L. 1998. Factors affecting the detection of potato mop-top virus in potato tubers and improvement of test procedures for more reliable assays. Ann. Appl. Biol. 133:55-63.

28. Stevenson, W. R., Loria, R., Franc, G. D., and Weingartner, D. P. eds. 2001. Compendium of Potato Diseases, 2nd ed. The American Phytopathological Society, St. Paul, MN.

29. Sutula, C. L., Gillet, J. M., Morrissey, S. M., and Ramsdell, D. C. 1986. Interpreting ELISA data and establishing the positive-negative threshold. Plant Dis. 70:722-726.

30. Tenorio, J., Franco, Y., Chuquillanqui, C., Owens, R. A., and Salazar, L. F. 2006. Reaction of potato varieties to Potato mop-top virus infection in the Andes. Am. J. Potato Res. 83:423-431.
31. Turechek, W. W. 2004. Nonparametric tests in plant disease epidemiology: Characterizing disease associations. Phytopathology 94:10181021

32. Van de Graaf, P., Lees, A. K., Cullen, D. W., and Duncan, J. M. 2003. Detection and quantification of Spongospora subterranea in soil, water and plant tissue samples using real-time PCR. Eur. J. Plant Pathol. 109:589-597.

33. Van de Graaf, P., Lees, A. K., Wale, S. J., and Duncan, J. M. 2005. Effect of soil inoculum level and environmental factors on potato powdery scab caused by Spongospora subterranea. Plant Pathol. 54:22-28.

34. Vásquez, V., Montero-Astúa, M., and Rivera, C. 2006. Incidencia y distribución altitudinal de 13 virus en cultivos de Solanum tuberosum (Solanaceae) en Costa Rica. Rev. Biol. Trop. (Int. J. Trop. Biol.) 54(4):1135-1141.

35. Wale, S. 2000. Summary of the session on national potato production and the powdery scab situation. Pages 3-9 in: Proc. First Eur. Powdery Scab Workshop. U. Merz and A. K. Lees, eds. Scottish Agricultural College, Craibstone Estate, Aberdeen, Scotland.

36. Wale, S. 2000. The powdery scab situation in Scotland. Page 11 in: Proc. First Eur. Powdery Scab Workshop. U. Merz and A. K. Lees, eds Scottish Agricultural College, Craibstone Estate, Aberdeen, Scotland.

37. Wallace, A., Williams, N. A., Lowe, R., and Harrison, J. G. 1995. Detection of Spongospora subterranea using monoclonal antibodies in ELISA. Plant Pathol. 44:355-365.

38. Walsh, J. A., Merz. U., and Harrison, J. G. 1996. Serological detection of spore balls of Spongospora subterranea and quantification in soil. Plant Pathol. 45:884-895.

39. Xu, H., Dehaan, T.-L., and De Boer, S. H 2004. Detection and confirmation of Potato mop-top virus in potatoes produced in the United States and Canada. Plant Dis. 88:363367.

40. Zar, J. H. 1999. Biostatistical Analysis, 4th ed. Prentice Hall, Upper Saddle River, NJ. 